\title{
Pengaruh Kepemimpinan Kepala Madrasah dan Komitmen Guru Terhadap Efektifitas Madrasah di Lhokseumawe
}

\author{
Muhammad Fadhli ${ }^{1}$ \\ ${ }^{1}$ Institut Agama Islam Negeri (IAIN) Lhokseumawe, Indonesia
}

Corresponding Author: Muhammad Fadhli, E-mail: fadhlikhan88@gmail.com

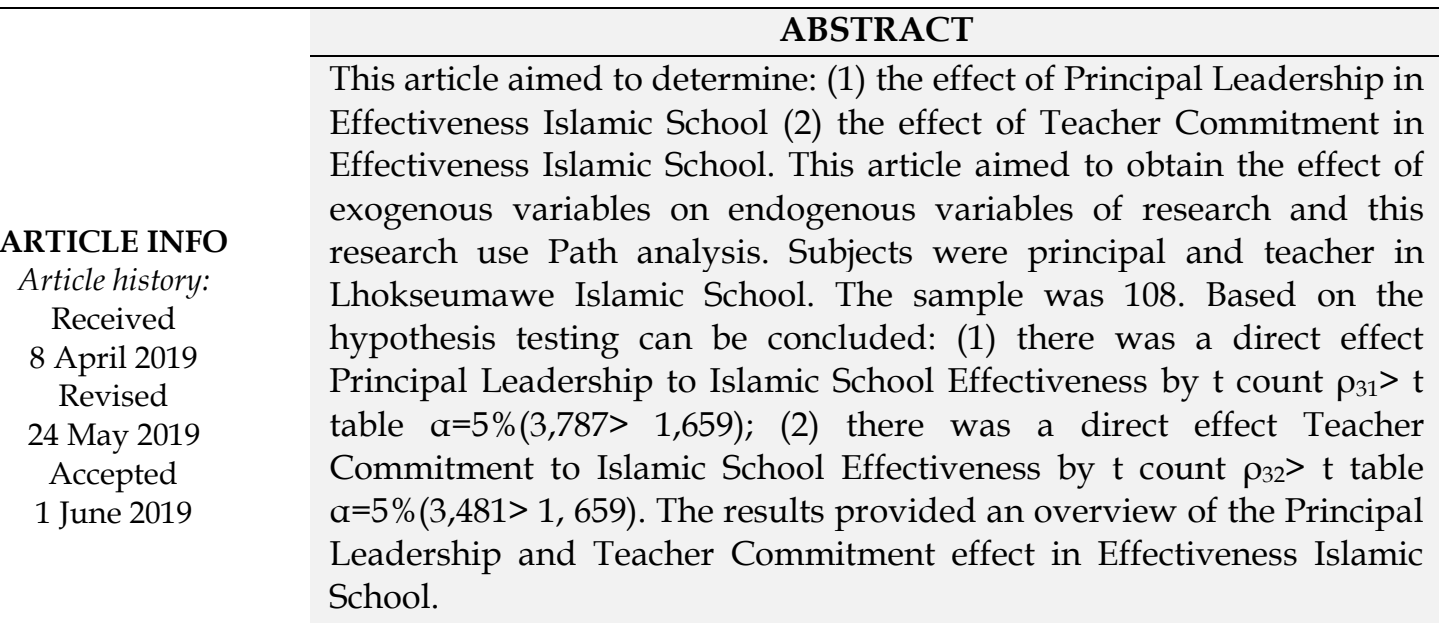

Key words: Principle Leadership, Teacher Commitment, Effectiveness of Islamic School

DOI $\quad:$ https://doi.org/10.25217/ji.v4i1.447

Journal Homepage $\quad$ : http://journal.iaimnumetrolampung.ac.id/index.php/ji/

This is an open access article under the CC BY SA license

: https://creativecommons.org/licenses/by-sa/4.0/

\section{PENDAHULUAN}

Pentingya madrasah bagi umat Islam khususnya di Indonesia, merupakan tanggungjawab mulia yang harus diemban para stakeholder madrasah. Untuk itu para stakeholder madrasah harus memberikan yang terbaik bagi umat Islam dalam mengemban pendidikan. Maka beberapa bentuk upaya yang dapat dilakukan adalah upaya-upaya secara berkelanjutan dalam meningkatkan mutu madrasah.

Madrasah yang bermutu tentunya adalah madrasah yang dapat mencapai efektivitas dalam pengelolaannya. Senada dengan hal ini Sagala menjelaskan bahwa keefektifan sekolah (effective schooling) dan yang sekolah yang bermutu (school quality) merupakan yang tak kunjung habis-habisnya, sepanjang sekolah itu masih menjalankan kegiatannya (Sagala, 2010). Artinya seiring dengan tuntunan akan perubahan yang terus menerus mengikuti 
perkembangan zaman melalui perkembangan ilmu pengetahuan dan teknologi (IPTEK), tuntutan akan keefektifan dan mutu sekolah mengiringinya.

Lahirnya undang-undang nomor 20 tahun 2003 tentang sistem pendidikan nasional menjadi angin segar bagi pendidikan madrasah. Hal ini dikarenakan dalam undang-undang tersebut selalu meyandingkan kata "sekolah" dengan "madrasah". Hal ini tentunya berarti bahwa negara melalui peraturan perundang-undangannya telah menyatakan bahwa sekolah dan madrasah memiliki kedudukan yang sama.

Namun hingga saat ini sebahagian masyarakat masih menganggap bahwa madrasah merupakan lembaga pendidikan yang di-nomor-duakan. Pendapat ini tidak sepenuhya benar namun juga tidak sepenuhnya salah. Tidak sepenuhnya benar dikarenakan saat ini banyak madrasah yang memiliki mutu dan efektivitas yang sangat baik seperti Madrasah Insan Cendekia yang merupakan program unggulan dari Kementerian Agama. Tidak sepenuhnya salah pendapat tersebut dikarenakan masih banyak madrasah yang justru memiliki mutu yang sangat memprihatinkan baik dari segi sarana dan prasarana sampai profesionalisme pendidik dan tenaga kependidikannya. Permasalahan mutu madrasah paling banyak terjadi pada madrasah swasta.

Banyaknya permasalahan pada madrasah swasta tentunya menjadi masalah besar dalam eksistensi madrasah di Indonesia. Hal ini dikarenakan, menurut data dari Kementerian Agama yang dikutip oleh Muchaddam (2013) tentang jumlah madrasah, jumlah madrasah swasta atau madrasah yang diselenggarakan oleh masyarakat jauh lebih banyak dibandingkan madrasah negeri. Madrasah Ibtidaiyah Negeri, hanya ada 7,5\%, sisanya 92,5\% adalah swasta. Kemudian MTs negeri ada 9,7\%dan MTs Swasta ada 90,3\%.Selanjutnya untuk Aliyah negeri hanya ada $11,8 \%$ negeri dan $88,2 \%$ adalah madrasah swasta. Data ini memberikan makna bahwa lebih dari $85 \%$ madrasah di Indonesia adalah madrasah swasta.

Permasalahan berikutnya yang tampak adalah permasalahan akreditasi. Dari data akreditasi madrasah Jenjang MTs pada tahun 2011 hanya ada sebesar $46 \%$ madrasah yang telah terakreditasi. Kurang dari 50\% madrasah yang terakreditasi. Hal ini tentunya akan menjadi tantangan besar bagi Kementerian Agama. Dalam kerangka strategis program akreditasi madrasah Direktorat Pendidikan Madrasah yang tertuang dalam Rencana strategik pembangunan pendidikan Islam tahun 2010-2014, Direktorat Jenderal Pendidikan Islam menargetkan 100\% madrasah terakreditasi pada tahun 2014, dan 50\% madrasah mendapatkan/memperoleh akreditasi "B". Sampai saat ini target Direktorat Madrasah ini belum tercapai sepenuhnya. 
Masih banyaknya madrasah yang belum terakreditasi tentunya menjadikan gambaran bahwa madrasah belum memiliki mutu serta efektivitas yang standar. Akreditasi lembaga persekolahan atau madrasah merupakan salah satu wujud dari tercapaianya mutu suatu madrasah. Ketercapaian akreditasi madrasah bermakna bahwa madrasah telah memenuhi delapan standar nasional pendidikan yakni Standar Kompetensi Lulusan, Standar Isi, Standar Proses, Standar Pendidikan dan Tenaga Kependidikan, Standar Sarana dan Prasarana, Standar Pengelolaan, Standar Pembiayaan Pendidikan, Standar Penilaian Pendidikan.

Kondisi yang sama juga masih banyak terjadi di MTs yang ada di Kota Lhokseumawe. Masih ada madrasah yang belum memilki sarana dan prasarana yang sesuai dengan standar, pembiayaan yang masih dikatakan "pas-pasan", kempemimpin kepala madrasah yang belum maksimal hal ini dibutikan belum adanya seleksi dan kriteria yang jelas dari Kementerian Agama dalam pemilihan Kepala Madrasah, partisipasi orang tua dan masyarakat yang belum maksimal.

Banyaknya permasalahan tersebut tentunya menjadi tanggung jawab bersama seluruh stakeholder madrasah. Upaya yang dapat dilakukan adalah dengan menciptakan dan menigkatkan mutu madrasah. Untuk dapat meningkatkan mutu madrasah adalah dengan mencapai efektivitas madrasah tersebut.

Tatlah \& Iqbal (2013) menemukan sebuah pencapaian efektivitas madrasah sangat memilki hubungan yang cukup besar dengan gaya kepemimpinan kepala madrasah. Kemudian Hasil penelitian Lezotte dalam (Sagala, 2010) mengutarakan, berbagai upaya dalam meningkatkan kualitas lembaga pendidikan kearah yang lebih baik, sebagai contoh negara Amerika melakukan berbagai reformasi dalam sistem sekolahnya sebagai upaya yang telah dilakukan untuk meningkatkan mutu sekolah kesemuanya diperuntukkan kepada pencapaian efektivtas sekolah. Hal ini memberikan penegasan untuk meningkatkan mutu sekolah maka upaya yang dilakukan terlebih dahulu adalah mencapai efektivitas sekolah. Berdasarkan studi ini maka upaya-upaya yang dapat dijadikan sebagai landasan peningkatan mutu pendidikan dan mutu sekolah/madrasah adalah dengan mewujudkan efektivtas sekolah/ madrasah.

Dalam menciptakan efektivitas sekolah, Mulyasa (2012) mengungkapkan sedikitnya sekolah tersebut harus memiliki sembilan karakteristik yaitu: (1) adanya perencanaan dan pengembangan sekolah, (2) meningkatkan pengembangan guru dan staff, (3) pengembangan peserta didik,( 4) melibatkan masyarakat dan orangtua, (5) pemberian penghargaan dan insentif kepada staff 
sekolah, (6) adanya regulasi yang berkaitan dengan tata tertib dan disiplin, (7) manajemen kurikulum dan pembelajaran, (8) manajemen keuangan dan pembiayaan, (9) serta manajemen fasilitas sekolah yang tepat.

Scheerens dan Bosker dalam Sugiyono (2011)mengungkapkan faktorfaktor yang mempengaruhi keefektifan sekolah yaitu: (1) Achiefment orientation, (2) Educational leadership, (3) Consensus and cohesion,(4) Curriculum quality, (5) School climate, (6) Classrom climate, (7) Parental involvement, (8) Evaluative potensial, (9) Effective learning time, (10) Structured instruction, (11) Independent learning, (12) Adaptive instruction, (13) Feedback and reinforcement. Dari uraian di atas dapat terlihat bahwa sebenarnya banyak faktor yang mempengaruhi keefektifan sekolah.

Kemudian Bush melakukan penelitian di 12 sekolah efektif di Inggris dan Wales yang menemukan bahwa kepemimpin kepala madrasah yang baik seperti memberika informasi dan mengomunikasikan nilai-nilai yang baik akan berdampak pada pencapain tujuan sekolah (Bush, 2008). Pandangan ini berarti bahwa kepemimpinan memikili pengaruh besar terhadap efektivitas sekolah/madrasah. Selanjutnya Komariah dan Triatna menguraikan bahwa sekolah yang mampu mencapai efektivitasnya adalah sekolah yang menunjukkan standar yang tinggi dari berbagai bidang mulai dari prestasi akademik, memilki budaya yang mendukung pencapaian tujuan, kepemimpinan yang baik dan memilki rumusan visi dan misi yang dibuat bersama stakeholder sekolah, serta guru-guru yang berkomitmen (Komariah \& Triatna, 2008).

Dari berbagai pendapat para ahli di atas selalu menempatkan kepemimpinan sebagai faktor utama dalam menciptakan efektivtas madrasah. Kepala madrasah merupakan salah satu faktor penting dalam menciptakan efektivtas madrasah. Begitu juga sebaliknya efektivtas madrasah hanya dapat diciptakan melalui kepemimpinan yang kuat dan tangguh yang harus dimiliki oleh kepala madrasah.

Selain kepemimpinan kepala madrasah, guru yang memiliki komitmen kuat terhdap organisasi atau madrasah menjadi sangat penting dalam upaya menciptakana efektivtas madrasah. Guru merupakan ujung tombak dalam dunia pendidikan. Walapun Seluruh aspek madrasah sudah terpenuhi seperti sarana dan prasarana, pembiayaan dan lain sebagainya tidak akan berguna jika madrasah tidak memiki guru yang berkualitas. Namun sebaliknya, jika guru memiliki komitmen yang kuat tentunya akan memberikan dampak yang baik bagi kemajuan madrasah. Dengan demikian dapat ditarik sebuah kesimpulan, bahwa selain kepemimpinan kepala madrasah, komitmen guru memilki peranan penting dalam menciptakan efektivitas madrasah. 
Dalam studinya Altun mengeksplorasi komitmen guru dalam upaya memberikan kontirbusi pada prestasi siswa. Komitmen guru akan menimbulkan semangat, menunjukkan efek gairah pada saat mengajar dan sehingga menghasilkan pembelajaran yang efektif. Temuan penelitian ini komitmen guru akan berdampak pada menghormati siswa, memiliki rasa kepedulian, mendengarkan masalah siswa, memberikan motivasi, memilki komitmen, mengajar dengan penuh gairah (Altun, 2017). Ramberg dkk dalam penelitiannya menemukan bahwa dalam kajian efektivitas sekolah di masa depan adalah untuk menyelidiki lebih lanjut hubungan antara persepsi guru yang memeilki kepedulian dengan prestasi akademik dan sosial siswa (Ramberg et al. 2019).

Penelitian tentang upaya menciptakan madrasah efektif sangat penting mengingat banyaknya madrasah yang belum mencapai mutu yang baik. Selama ini kajian-kajian tentang efektif lembaga pendidikan jarang dilakukan terutama dilembaga pendidikan Islam (madrasah). Oleh karena itu penting dilakukan studi tentang upaya untuk menghasilkan madrasah-madrasah efektif.

\section{Madrasah Efektif}

Madraah merupakan organisasi dan setiap organisasi bercita-cita untuk mencapai tujuannya. Tujuan yang diinginkan oleh setiap organisasi yaitu efektif. Efektivitas sebuah organisasi meruapak tujuan akhir dari terselenggaranya proses manajemen yang baik. Robbins \& Coulter (2018) menjelaskan bahwa proses dalam manajemen melibatkan koordinasi dan pengawasan setiap kegiatan pekerjaan orang lain atau anggota organisasi sehingga kegiatan yang dikerjakan dapat diselesaikan secara efisien dan efektif".

Ada kaitan erat antara proses manajemen yang baik dengan pencapain organisasi atau lebih dikenal dengan efektivitas organisasi. Certo \& Certo (2012) menyatakan "...the management process as it pertains to management function and organizational goal attaintment, and the need to manage organizational resources effectively and efficiently". Dalam setiap proses manajemen yang didalamnya berkaitan dengan fungsi manajemen dan upaya pencapaian tujuan organisasi, serta kemampuan untuk memberdayakan sumber daya organisasi baik sumberdaya manusia, fasilitas maupun finansial yang semuanya berupaya mewujudkan tujuan organisasi secara efektif dan efisien.

Efektivitas madrasah dapat di raih dengan menggabungkan manajemen budaya yakni penyusunan tujuan dan makna dari tujuan tersebut dengan manajemen kinerja yakni kemampuan mengukur apa yang benar-benar 
penting sehingga menjadi prioritas. Sebagaimana pendapat Morley \& Rassool (2003) menegaskan bahwa "school effectiveness combines culture management (the creation of purposes and meanings) with performance management (measuring what really matters)". Kemampuan Madrasah dalam mencapai efektivitasnya ditentukan terhadap kemauan menggabubngkan keduanya yakni manajemen budaya dan manajemen kinerja.

Uapaya-upaya meeningkatkan lembaga pendidikan Islam sebagai cara untuk perubahan pendidikan berlandarkan pada sejumlah asumsi yang disimpulkan oleh Cyril Poster (1999) sebagai beriku:

1) The school is the centre of change. (Sekolah sebagai pusat perubahan).

2) There is a systematic approach to change. (Ada pendekatan sistematis untuk berubah).

3) The 'internal conditions' of schools are a key focus for change. ('Kondisi internal' sekolah adalah fokus utama untuk perubahan).

4) Educational goals are accomplished more effectively. (Tujuan pendidikan tercapai dengan lebih efektif)

5) There is a multi-level perspective. (ada perspektif yang banyak)

6) Implementation strategies are integrated. (penerapan strategi yang terintegrasi).

7) There is a drive towards institutionalism (Ada dorongan menuju institusionalisme).

Hal ini memberikan penguatan bahwa kerjasama antar semua komponen atau stakeholder sangat penting dalam upaya pencapaian efketivitas Madrasah. Efketivitas Madrasah tidak akan dapat diwujudkan apabila seluruh stakeholder tidak dapat bersinergi. Sekolah atau madrasah yang efektif harus mencapai hasil atau tujuannya sesuai dengan apa yang telah direncanakan dan ditetapkan sebelumnya. Sekolah efektif dapat memberikan harapan-harapan bahkan jaminan kepada pemangku kepentingan bahwa sekolah ini memilki kualitas dalam mendidik siswa.

\section{Kepemimpinan Kepala Madrasah}

Untuk mendefinisikan makna dari kepemipinan sangatlah sulit, apalagi untuk merumuskan suatu defenisi yang disepakati oleh semua orang. Hal ini terjadi karena perubahan yang sangat dinamis dan terjadi secara terus menerus. Latar belakang ahli yang berbeda juga memberikan kontribusi terhadap problematika dari sukarnya defenisi kepemimpinan itu sendiri. Namun hampur semua konsep kepemimpinan menyepakati bahwa kemampuan memepngaruhi orang lain untuk bekerjasama merupakan salah satu aspek penting dari kepemimpinan. 
Namun, pentingnya kepemimpinan dalam sebuah organisasi mutlak adanya. Tidak ada satu ahli manajemen yang mengungkapkan bahwa organisasi tidak membutuhkan pemimpin yang memiliki kemampuan. Kepemimpinan dan manjerial yang baik merupakan syarat utama organisasi berjalan dengan efektif. leadership is offered as a solution for most of the problems of organizations everywhere. Around the world, administrators and managers say that their organizations would thrive if only senior management provided strategy, vision, and real leadership (Palestini, 2009). Kepemimpinan adalah solusi untuk sebagian besar masalah organisasi baik organisasi profit maupun non profit. Seleruh manajer dan administrator mengatakan bahwa organisasi akan berkembang, jika hanya manajemen puncak yang memilki strategi, visi, dan kepemimpinan yang nyata.

Nahavandi (2015) memberikan pandangan bahwa setiap orang yang memilki kemampuan untuk dapat mempengaruhi individu atau kelompok dalam suatu organisasi, kemudian dapat membantu mereka dalam menetapkan tujuan organisasi, serta membimbing mereka menuju pencapaian tujuan tersebut, sehingga memungkinkan mereka untuk menjadi efektif itu disebut sebagai sorang pemimpin. Sementara itu Daft memberikan penguatan kemampuan kepemimpinan adalah dapat mempengaruhi hubungan antara pemimpin dan anggota sebuah organisasi (followers) sehingga menginginkan perubahan dan hasil nyata bagi kemajuan dan keunggulan organisasi yang mencerminkan tujuan bersama setiap anggota organisasi.

Jika ditelaah lebih dalam, kepemimpinan memilki dua kata kunci utama yaitu mempengaruhi dan perubahan. Pengaruh atau mempengaruhi berarti bahwa hubungan antara pemimpin dan bawahan tidak pasif. Namun, yang juga melekat (inheren) dalam konsep mempengaruhi adalah hubungan banyak/ multi arah dan tanpa paksaan. Di sebagian besar organisasi, atasan mempengaruhi bawahan, tetapi tidak menutup kemungkinan bawahan juga dapat mempengaruhi atasan. Oleh karena itu dalam proses kepemimpinan adanya hubungan timbal balik.

Kata kunci yang kedua dari kepemimpinan yaitu perubahan. Orangorang yang terlibat dalam sebuah organisasi senantiasa menginginkan adanya perubahan yang substantif dan kepemimpinan adalah orang yang harus menciptakan perubahan itu. Perubahan harus di ciptakan dan perubahan tidak di harus didikte oleh para pemimpin, tetapi pemimpin dapat mendorong bawahan memberikan kontribusi positif untuk perubahan organisasi.

Stronge, Richard dan Catano memberikan perincian tentang kualitas kepemimpinan kepala sekolah yang efektif seperti pada Tabel 1 berikut (Stronge et al. 2008) ; 
Pengaruh Kepemimpinan Kepala Madrasah dan Komitmen Guru Terhadap Efektifitas Madrasah di Lhokseumawe

Tabel 1. Kualitas Kepala Sekolah Efektfif

\begin{tabular}{|c|c|}
\hline $\begin{array}{l}\text { Kualitas Kepala } \\
\text { Sekolah }\end{array}$ & Deskripsi \\
\hline $\begin{array}{l}\text { Instructional Leadership } \\
\text { (Kepemimpinan } \\
\text { Instruksional) }\end{array}$ & $\begin{array}{l}\text { Kepala Sekolah mendorong kesuksesan semua } \\
\text { siswa dengan memfasilitasi pengembangan, } \\
\text { komu-nikasi, implementasi, dan evaluasi visi } \\
\text { bersama pembelajaran yang mencerminkan } \\
\text { keunggulan. }\end{array}$ \\
\hline $\begin{array}{c}\text { School Climate (Iklim } \\
\text { Sekolah) }\end{array}$ & $\begin{array}{l}\text { kepala sekolah mendorong kesuk-sesan semua } \\
\text { siswa dengan mengan-jurkan, memelihara, dan } \\
\text { memperta-hankan iklim sekolah yang positif dan } \\
\text { aman bagi semua pemangku kepen-tingan. }\end{array}$ \\
\hline $\begin{array}{l}\text { Human Resource } \\
\text { Administration } \\
\text { (Administrasi SDM) }\end{array}$ & $\begin{array}{l}\text { Kepala Sekolah memupuk adminis-trasi sumber } \\
\text { daya manusia yang efektif melalui seleksi, } \\
\text { penempatan, dukungan, dan pembinaan personil } \\
\text { serta memberikan dukungan yang berkualitas }\end{array}$ \\
\hline $\begin{array}{l}\text { Teacher Evaluation } \\
\text { (Mengevaluasi Guru) }\end{array}$ & $\begin{array}{l}\text { Kepala sekolah melakukan evaluasi guru dan } \\
\text { anggota staf yang ber-makna, tepat waktu, dan } \\
\text { produktif untuk mendukung efektivitas kinerja } \\
\text { dan peningkatan kualitas sekolah. }\end{array}$ \\
\hline $\begin{array}{l}\text { Organizational } \\
\text { Management } \\
\text { (Manajemen } \\
\text { Organisasi) }\end{array}$ & $\begin{array}{l}\text { Kepala sekolah membentuk kesuksesan semua } \\
\text { siswa dengan mendukung, mengelola, } \\
\text { mengawasi organi-sasi, operasional, dan sumber } \\
\text { daya sekolah }\end{array}$ \\
\hline $\begin{array}{l}\text { Communication and } \\
\text { Community Relations } \\
\text { (Komunikasi dan } \\
\text { Humas) }\end{array}$ & $\begin{array}{l}\text { Kepala Sekolah mendorong kesuksesan semua } \\
\text { siswa dengan berkolaborasi secara efektif dengan } \\
\text { semua pemangku kepentingan }\end{array}$ \\
\hline $\begin{array}{l}\text { Professionalism } \\
\text { (Profesional) }\end{array}$ & $\begin{array}{l}\text { Kepal Sekolah mendorong kesuk-sesan semua } \\
\text { siswa dengan menun-jukkan integritas, keadilan, } \\
\text { dan etika dalam berprilaku }\end{array}$ \\
\hline $\begin{array}{l}\text { The Principal's Role in } \\
\text { Student Achievement } \\
\text { (Peran Kepala Sekolah } \\
\text { dalam Prestasi Siswa) }\end{array}$ & $\begin{array}{l}\text { Kepemimpinan kepala sekolah menghasilkan } \\
\text { kemajuan yang dapat diukur dan terukur } \\
\text { berdasarkan standar yang telah ditetapkan }\end{array}$ \\
\hline
\end{tabular}

Keberhasilan madrasah efektif sangat ditentukan pada kepemimpinan yang baik. Kepemimpinan yang baik hadir sebagai orang yang mampu membawa perubahan kearah yang lebih baik. kepemimpinan pendidikan Islam 
dapat diwujudkan dengan kepemimpinan yang memilki perhatian kepada pegawai, memilki komitmen pada guru dan staf sekolah, kinerja guru dan staf yang baik, sekolah memilki kesiapan dalam menghadapi perubahan dan persaiangan, guru dan staf memilki kepuasan kerja terhdap kepemimpinan kepala sekolah, meningkatnya kreativitas pembelajaran siswa yang bermuara pada prestasi siswa baik secara kognitif, afektif maupun psikomotorik.

\section{Komitmen Guru}

Komitmen organisasi berkaitan erat dengan kinerja dalam kajian perilaku organisasi, komitmen mencerminkan permulaaan dalam menentukan arah organisasi. Komitmen anggota organisasi sangat penting bagi sebuah organisasi, karena itu bagi sebuah organisasi tidak cukup memiliki karyawan yang berbakat dan dapat melakukan pekerjaan dengan baik tetapi tidak memilki komitmen. Organisasi yang sudah mampu mengembangkankan sumberdaya manusianya akan dirugikan apabila anggota organisasi tidak mau dipertahankan untuk bekerja lebih lama.

Komitmen yang tinggi akan menghasilkan kinerja yang tinggi dalam organisasi. Beer menjelaskan komitmen yang tinggi dan kinerja tinggi suatu lembaga mampu memberikan kinerja yang berkelanjutan secara terus menerus (Beer, 2009). Keberlanjutan ini dikarenakan komitmen yang tinggi dapat mengembangkan pilar organisasi berikut: 1) Kinerja yang selaras, 2) keselarasan Psikologis dan 3) Kapasitas untuk terus belajar dan berubah.

Colquitt, LePine, dan Wasson menjelaskan bahwa komitmen organisasi diartikan sebagai keinginan dari anggota organisasi untuk tetap menjadi anggota organisasi tersebut. Komitmen organisasi dapat memberikan pengaruh apakah seorang karyawan tetap mmilki keinginan menjadi anggota organisasi (dipertahankan) atau pergi untuk mengejar pekerjaan lain (keinginan pindah). Untuk itu setiap organisasi harus mampu memberikan rasa nyaman bagi oanggota organisasi untuk dapat terus mempertahankannya (Colquitt, Lepine, \& Wesson, 2015).

Komitemen pribadi erat kaitannya dengan komitmen dalam organisasi. Jika seseorang memiliki komitmen dalam organisasi dia akan menunjukkan kinerja yang tinggi. Komitmen organisasi adalah keterkaitan identitas seseorang dengan tampilan organisasi. Griffin \& Moorhead (2014) menjelaskan A highly committed person will probably see herself as a true member of the firm, overlook minor sources of dissatisfaction, and see herself remaining a member of the organization. In contrast, a less committed person is more likely to see herself as an outsider. Komitmen organisasi, atau juga sering diterminologikan sebagai komitmen kerja, mencerminkan identifikasi dan keterikatan individu dengan 
organisasinya. Setiap orang yang memiliki komitmen akan meyakini bahwa dirinya sebagai anggota sejati dari sebuah organisasi, mengabaikan sumber ketidakpuasan yang kecil, dan melihat dirinya sebagai anggota tetap organisasi. Sebaliknya, jika orang yang kurang berkomitmen justru lebih cenderung berpersepsi bahwa dirinya sebagai orang luar organisasi. Tidak ada rasa memilki terhadap organisasi tersebut.

Dalam pendidikan guru yang memliki komitmen organisasi sangat di butuhkan, tingginya komitmen seorang guru dalam organisasinya sangat berpengaruh terhadap kinerjanya dalam organisasi tersebut. Orang yang berkomitmen akan memilki arah dan tujuan yang sama dengan tujuan organisasi. Robbins dan Coulter menjelaskan komitmen organisasi adalah sejauh mana seorang guru mengetahui tujuan organisasi dan memilki keinginan yang kuat untuk mempertahankan keanggotaannya dalam organisasi itu (Robbins \& Coulter, 2018). Sedangkan keterlibatan kerja adalah mengenali dengan pekerjaannya sebagai guru, hasil penelitian menunjukkan bahwa komitmen organisasi juga mengarah ke tingkat yang lebih rendah dari absensi dan keinginan pindah, artinya jika seorang guru memiliki komitmen terhadap organisasinya maka kedisiplinannya akan sangat baik dan keinginannya untuk pindah ke lembaga lain akan rendah.

\section{METODE PENELITIAN}

Penelitian ini dilakukan dengan menggunakan metode kuantitatif. Model yang digunakan adalah model analisis jalur (path analysis) atau sering disebut dengan pola hubungan sebab akibat. Menurut Riduwan dan Kuncoro penelitian yang menggunakan analisis jalur bertujuan untuk memberikan analisis antara pola hubungan berbagai variabel untuk mendapatkan/mengetahui adanya pengaruh langsung maupun tidak langsung variabel bebas (eksogen) terhadap variabel terikat (endogen) (Riduwan \& Kuncoro, 2012). Teknik analisis data yang digunakan adalah teknik statistik deskriptif atau inferensial. Populasi dalam penelitian ini adalah seluruh kepala madrasah dan guru MTs Negeri dan Swasta Kota Lhokseumawe. Jumlah populasi penelitian ini adalah 20 Madrasah. Selanjutnya ditetapkan sampel sebanyak 18 Kepala Madrasah ditambah masing-masing 5 orang guru tiap madrasah, sehingga jumlah keseluruhan sampel adalah 108 orang. Sedang kandua madrasah lainnya dijadikan sebagai tempat ujicoba instrumen. Untuk menentukan responden, maka digunakan teknik random sampling. 


\section{HASIL PENELITIAN DAN PEMBAHASAN}

Hasil pengujian persyaratan analisis menunjukkan bahwa data Setiap variabel penelitian telah memenuhi persyaratan untuk dilakukan pengujian hipotesis statistik dan pengujian hipotesis penelitian. Deskripsi hasil perhitungan yang telah dilakukan dengan menggunakan analisis jalur terhadap hipotesis penelitian dijabarkan Sebagai berikut:

\section{Pengaruh kepemimpinan kepala madrasah $\left(X_{1}\right)$ terhadap efektivitas madrasah $\left(X_{3}\right)$}

Dari perhitungan koefisien jalur antara $X_{1}$ terhadap $X_{3}$ diperoleh $\rho_{31}=$ 0,345 dan harga $t_{\text {hitung }}=3,787$. Untuk $\mathrm{N}=108$ pada taraf signifikansi $5 \%$ diperoleh $t_{\text {tabel }}=1,659$. Hasil perhitungan menghasilkan $t_{\text {hitung }}>t_{\text {tabel }}(3,787>$ 1,659). Dengan demikian Ho ditolak dan Ha diterima, sehingga dapat disimpulkan bahwa kepemimpinan kepala madrasah berpengaruh langsung terhadap kepuasan kerja.

\section{Pengaruh komitmen guru $\left(X_{2}\right)$ terhadap efektivitas madrasah $\left(X_{3}\right)$}

Dari perhitungan koefisien jalur antara $X_{2}$ terhadap $X_{3}$ diperoleh $\rho_{32}=$ 0,320 dan harga $t_{\text {hitung }}=3,481$. Untuk $\mathrm{N}=108$ pada taraf signifikansi $5 \%$ diperoleh $t_{\text {tabel }}=1,659$. Hasil perhitungan menghasilkan $t_{\text {hitung }}>t_{\text {tabel }}(3,481>$ 1,659). Dengan demikian Ho ditolak dan Ha diterima, sehingga dapat disimpulkan bahwa komitmen guru berpengaruh langsung terhadap kepuasan kerja.

Untuk lebih jelasnya, berikut ini disajikan rangkuman estimasi koefisien jalur pada tabel 2

Tabel 2. Rangkuman Estimasi Koefisien Jalur

\begin{tabular}{|l|l|l|l|l|}
\hline Variabel & Koefisien & $t_{\text {hitung }}$ & $t_{\text {tabel }}$ & Hasil \\
\hline$\rho_{31}$ & 0,345 & 3,787 & \multirow{2}{*}{1,659} & Berarti \\
\cline { 1 - 3 }$\rho_{32}$ & 0,320 & 3,481 & & Berarti \\
\hline
\end{tabular}

\section{Pengaruh Kepemimpinan Kepala Madrasah Terhadap Kepuasan Kerja Guru}

Temuan pertama yakni kepemimpinan kepala madrasah menunjukkan pengaruh posistif dan signifikan dengan kepuasan kerja guru dengan besaran 
11,9\%. Dari hasil temuan ini dapat ditarik sebuah kesimpulan bahwa efektivtas madrasah sangat dipengaruhi oleh etos kerja kepala sekolah. Wu et al. (2016) juga menemukan bahwa ada korelasi positif yang signifikan antara kepemimpinan kepala sekolah dengan upaya pembentukan efektivitas sekolah Namun dalam penelitian ini peran kepala sekolah sangat dipengaruhi oleh budaya organisasi. Kepala sekolah sebenarnya memberi kontribusi terhadap budaya organisasi dilembaganya.

Kepala sekolah merupakan pemimpin utama dalam sebuah lembaga pendidikan untuk itu, maka Kepala Sekolah berkewajiban untuk dapat mewujudkan dan menciptakan sekolah/madrasah yang efektif. Madrasah harus mampu merespon perubahan dan perkembangan zaman yang semakin cepat pada saat ini. Tugas Kepala madrasah untuk mampu membawa dan mendampingi semua sumberdaya madrasahnya untuk mampu menghadapi dan meresopn hal tersebut. Sebagaimana yang diungkapakan oleh Bush berbagai kajian tentang kepemimpinan dalam pendidikan telah mengalami peningkatan sejak abad ke-20. Tingginya minat ini dikrenakan ada keyakinan yang kuat bahwa kepemimpinan dalam pendidikan mampu membuat perbedaan terhadap pencapain sekolah dan peningkatan prestasi siswa. Di berbgai negara baik negara maju maupun yang sedang berkembang terdapat pengakuan bahwa kepemimpinan sangat diperlukan jika ingin mendapatkan lembaga-lembaga pendidikan yang berkualitas dan efektif (Bush, 2008).

Temuan memberikan penjelasan bahwa kualitas kepemimpinan kepala madrasah berpengaruh terhadap efektivitas madrasah. Karenanya semakin baik kepemimpinan kepala madrasah akan semakin baik pula efektivitas madrasah. Berdasarkan hasil penelitian, pembahasan dan kesimpulan penulis memberikan rekomendasi untuk mewujudkan keefektifan sekolah dapat dilaksanakan dengan meningkatkan iklim organisasi dan etos kerja kepala sekolah. Implementasi visi dan penciptaan visi memiliki korelasi yang tinggi terhadap budaya sekolah maupun efektifitas sekolah.

\section{Pengaruh Komitmen Guru Terhadap Kepuasan Kerja Guru}

Temuan kedua yakni komitmen guru menunjukkan pengaruh posistif dan signifikan dengan kepuasan kerja guru dengan besaran 10,3\%. Ahmad juga dalam penelitiannya menyatakan bahwa komitmen guru tampaknya menjadi kontribusi tertinggi di antara prediktor terhadap efektivitas sekolah. Namun hanya faktor kepemimpinan yang memiliki kontribusi yang signifikan terhadapefektivitas sekolah (Rusmini Ku Ahmad, 2016). Hasil kajian Abdullah, Yiing dan Ling dalam temuan penelitiannya menjelaskan bagaimana semangat 
guru perlu diperkuat untuk meningkatkan efektivitas sekolah (Abdullah, Yiing, \& Ling, 2016).

Selanjutnya komitmen yang tinggi akan menghasilkan kinerja yang tinggi dalam organisasi. Beer menjelaskan adanya komitmen tinggi dalam sebuah organisasi akan mampu berdampak pada tingginya kinerja yang berkelanjutan (Beer, 2009). Komitmen yang tinggi dan kinerja tinggi suatu lembaga mampu memberikan kinerja yang berkelanjutan secara terus menerus. Keberlanjutan ini dikarenakan komitmen yang tinggi dapat mengembangkan pilar organisasi berikut: 1) kinerja yang selaras, 2) keselarasan psikologis, dan 3) kapasitas untuk terus belajar dan berubah. Atas dasar ini maka jika komitmen guru semakin baik terutama dalam menjalankan tugas maka tujuan pencapain efektivitas madrasah akan lebih mudah untuk diwujudkan.

Hasil studi dalam penelitian tentang upaya menciptakan madrasah efektif melalui kontribusi kepemimpinan kepala sekolah dan komitmen guru menunjukkan bahwa kedua variabel ini merupakan poin penting yang dapat dijadikan dasar dalam menciptakana madrasah efektif. Mengingat keterbatasan madrasah terutama madrasah swasta dalam pemenuhan faktor lainnya seperti pembiayaan, fasilitas serta dukungan dari orang tua dapat di eliminir melalui penguatan aspek kepemimpinan dan komitmen guru dalam pencapain prestasi siswa. Madrasah efektif merupakan gerbang utama dalam menghasilkan mutu madrasah, oleh karena itu setiap stakeholder harus berfokus pada pencapaian madrasah efektif jika ingin membuat madrasah-madrasah berkualitas.

\section{KESIMPULAN}

Sebagai kesimpulan dalam penelitian ini yang dilandasi hasil temuan, analisis dan pembahasan adalah sebagai berikut:

1. Kepemimpinan kepala madrasah berpengaruh secara langsung positif terhadap efektivitas Madrasah Tsanawiyah (MTs) Kota Lhokseumawe, artinya semakin baik kepemimpinan kepala madrasah, maka semakin baik juga efektivitas MTs Kota Lhokseumawe.

2. Komitmen guru berpengaruh langsung positif terhadap efektivitas MTs Kota Lhokseumawe, artinya semakin baik komitmen guru maka semakin baik juga efektivitas MTs Kota Lhokseumawe. 


\section{DAFTAR PUSTAKA}

Abdullah, A. G. K., Yiing, M. H., \& Ling, Y.-L. (2016). Teachers ' Morale and School Effectiveness in Secondary Schools of Sibu, Sarawak. International Journal of Education, Culture and Society, 1(2), 52-57. https://doi.org/10.11648/j.ijecs.20160102.14

Altun, M. (2017). The Effects of Teacher Commitment on Student Achievement. International Journal of Academic Research in Business and Social Sciences, 7(11), 417-426. https:/ / doi.org/10.23918/ijsses.v3i3p51

Beer, M. (2009). High Commitment, High Performance. San Francisco: Jossey-Bass.

Bush, T. (2008). Leadership and Management Development in Education. Los Angeles: SAGE Publications.

Certo, S. C., \& Certo, S. T. (2012). Modern Management: Concepts and Skills (12 ed.). New Jersey: Pearson.

Colquitt, J. A., Lepine, J. A., \& Wesson, M. J. (2015). Organizational Behavior: Improving Performance and Commitment in the Workplace (4 ed.). New York: McGraw-Hill.

Cyril Poster. (1999). Restructuring: The key to effective school management. New York: Routledge.

Daft, R. L. (2008). The Leadership Experience (4 ed.). Mason: Thomson SouthWestern.

E. Mulyasa. (2012). Manajemen dan Kepemimpinan Kepala Sekolah. Jakarta: Bumi Aksara.

Griffin, R. W., \& Moorhead, G. (2014). Organizational Behavior: Managing People and Organizations (11 ed.). Mason: South-Western.

Komariah, A., \& Triatna, C. (2008). Visionary Leadership Menuju Sekolah Efektif. Jakarta: Bumi Aksara.

Morley, L., \& Rassool, N. (2003). School Effectiveness: Fracturing the Discourse. New York: Falmer Press.

Muchaddam. F. (2013). Pemenuhan Standar Nasional Pendidikan Di Madrasah. Info Singkat, 5(11), 9-12.

Nahavandi, A. (2015). The Art and Science of Leadership (7 ed.). Edinburgh: Pearson.

Palestini, R. (2009). From Leadership Theory to Practice : a Game Plan for Success as a Leader. Maryland: Rowman \& Littlefield Education.

Ramberg, J., Låftman, S. B., Almquist, Y. B., \& Modin, B. (2019). School effectiveness and students' perceptions of teacher caring: A multilevel 
Pengaruh Kepemimpinan Kepala Madrasah dan Komitmen Guru Terhadap Efektifitas Madrasah di Lhokseumawe

study. Improving Schools, 22(1), 55-71. https://doi.org/10.1177/1365480218764693

Riduwan, \& Kuncoro, E. A. (2012). Cara Menggunakan dan Memakai Path Analysis. Bandung: Alfabeta.

Robbins, S. P., \& Coulter, M. (2018). Management (14 ed.). Harlow: Pearson.

Rusmini Ku Ahmad. (2016). Relation of leadership, teachers' commitment, teachers' competency, best practices to school effectiveness. Institut Aminuddin Baki Institute of Educational Management.

Sagala, S. (2010). Manajemen Strategik dalam Peningkatan Mutu Pendidikan. Bandung: Alfabeta.

Stronge, J. H., Richard, H. B., \& Catano, N. (2008). Qualities of effective Principals. virginia: Association for Supervision and Curriculum Development.

Sugiyono. (2011). Metode Penelitian Pendidikan (Pendekatan Kuantitatif, Kualitatif dan RED). Bandung: Alfabeta.

Tatlah, I. A., \& Iqbal, M. Z. (2013). Leadership Styles and School Effectiveness: Empirical Evidence from Secondary Level. Procedia - Social and Behavioral Sciences, $\quad$ 69(Iceepsy),

790-797. https://doi.org/10.1016/j.sbspro.2012.11.474

Wu, H.-T., Chen, C.-Y., Tsai, S.-S., \& Chen, H.-W. (2016). The relationship between the principal's positive leadership and school effectiveness take school organizational culture as the mediator. European Journal of Psychological Research, 3(2), 12-23. 